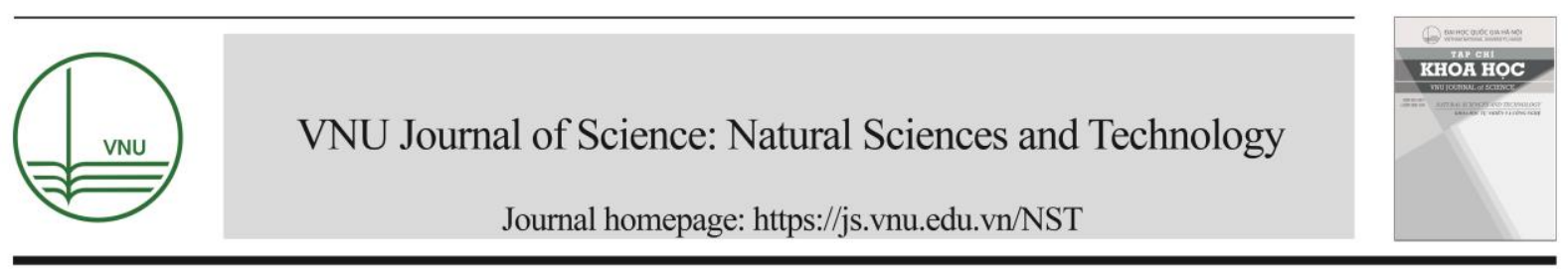

\title{
Low-Temperature $\mathrm{ZnO}$ Thin Film and Its Application in $\mathrm{PbS}$ Quantum Dot Solar Cells
}

\author{
Mai Xuan Dzung ${ }^{1, *}$, Hoang Quang Bac ${ }^{1}$, \\ Dinh Thi Cham ${ }^{1}$, Le Quang Trung ${ }^{1}$, Nguyen Trong Tung ${ }^{2}$, \\ Duong Ngoc Huyen ${ }^{2}$, Mai Van Tuan ${ }^{2,3}$, Le Dinh Trong ${ }^{4}$ \\ ${ }^{1}$ Department of Chemistry, Hanoi Pedagogical University 2, 32 Nguyen Van Linh, Phuc Yen, Vinh Phuc \\ ${ }^{2}$ School of Engineering Physics, Hanoi University of Science and Technology, 1 Dai Co Viet, Hanoi \\ ${ }^{3}$ Faculty of Natural Sciences, Electric Power University, 235 Hoang Quoc Viet, Hanoi \\ ${ }^{4}$ Department of Physics, Hanoi Pedagogical University 2, 32 Nguyen Van Linh, Phuc Yen, Vinh Phuc
}

Received 04 October 2017

Revised 10 September 2018; Accepted 10 September 2018

\begin{abstract}
Zinc oxide ( $\mathrm{ZnO})$ has been widely deployed as electron conducting layer in emerging photovoltaics including quantum dot, perovskite and organic solar cells. Reducing the curing temperature of $\mathrm{ZnO}$ layer to below $200{ }^{\circ} \mathrm{C}$ is an essential requirement to reduce the cell fabrication cost enabled by large-scale processes such as ink-jet printing, spin coating or roll-roll printing. This paper presents a novel water-based $\mathrm{ZnO}$ precursor stabilized with labile $\mathrm{NH}_{3}$, which allows the spinning of coat crystalline $\mathrm{ZnO}$ thin films at a temperature below $200{ }^{\circ} \mathrm{C}$. Thin film transistors (TFTs) and diode-type quantum dot solar cells (QD SCs) were fabricated with $\mathrm{ZnO}$ as electron conduction layer. In the QD SCs, a $p$-type 1,2-ethylenedithiol treated PbS QDs with a bandgap of $1.4 \mathrm{eV}$, was spin-coated on top of $\mathrm{ZnO}$ layer by a layer-by-layer solid state ligand exchange process. Electron mobility of $\mathrm{ZnO}$ was about $0.1 \mathrm{~cm}^{2} \mathrm{~V}^{-1} \mathrm{~s}^{-1}$ as determined from TFT measurements. Power conversion efficiency of solar cells: FTO/ZnO/PbS/Au-Ag was 3.0\% under AM1.5 irradiation conditions. The possibility of deposition of $\mathrm{ZnO}$ at low temperatures plays an important role in producing low-cost electronic and optoelectronic devices.
\end{abstract}

Keywords: $\mathrm{ZnO}$, low-temperature, quantum dot solar cell, TFTs.

\section{Introduction}

Zinc oxide $(\mathrm{ZnO})$ and titanium oxide $\left(\mathrm{TiO}_{2}\right)$ are the most transparent, $n$-type semiconductors

\footnotetext{
*Corresponding author. Tel.: 84-962938394.

Email: xdmai@hpu2.edu.vn

https://doi.org/10.25073/2588-1140/vnunst.4788
}

deployed in electronics, optoelectronics and photocatalyst. In comparison with $\mathrm{TiO}_{2}, \mathrm{ZnO}$ has a lower chemical stability and a shorter electron diffusion length. However, $\mathrm{ZnO}$ has a higher electron mobility and, especially it can be processed at much lower temperatures [1]. Therefore, $\mathrm{ZnO}$ has been attempted for largescale and/or flexible optoelectronic devices 
where low temperature annealing is an essential requirement [2-4].

There are two conventional methods for low-temperature $\mathrm{ZnO}$ thin films including solgel and sintering of pre-synthesized colloidal $\mathrm{ZnO}$ nanoparticles. The later usually suffers from low stability of colloidal dispersion. Solgel method is preferredbecause not only it is compatible with solution-based fabrication techniques such as ink-jet printing, roll-roll printing, spray coating and spin coating but also it facilitates varying the chemical composition of final solids. Mixture of Zinc acetate and ethanolamine in 2-methoxyethanol has been deployed widely to fabricate $\mathrm{ZnO}$ thin films with annealing temperatures ranging from 200 to $300{ }^{\circ} \mathrm{C}[6,7]$. The thermal annealing step that is conducted after solution coating is to induce the condensation reaction between $\mathrm{Zn}-\mathrm{OH}$ groups and to evaporate organic components such as solvent, ethanolamine and its salts. Herein, we used labile $\mathrm{NH}_{3}$ to stabilize $\mathrm{ZnO}$ clusters in aqueous solution and enabled to reduce the annealing temperature to below 200 ${ }^{\circ} \mathrm{C}$. The results must perceive much interests for future flexible electronics and optoelectronics $[6,7]$.

\section{Materials and methods}

2.1. Fabrication of $\mathrm{ZnO}$ thin films, thin films transistors and quantum dot solar cells

\subsubsection{Fabrication of $\mathrm{ZnO}$ thin films}

$\mathrm{ZnCl}_{2}$ (Semiconducting grade, $99.999 \%$, Sigma-Aldrich) was dissolved in concentrated $\mathrm{NH}_{4} \mathrm{OH}$ solution $\left(28 \%\right.$, Aladdin) at $5{ }^{\circ} \mathrm{C}$ to get a10 weight percent solution, which was stored at $5{ }^{\circ} \mathrm{C}$ in a refrigerator for further uses. Substrates including glasses, quartz, fluorinedoped Tin oxide glasses (FTO) and $\mathrm{p}-\mathrm{Si}^{++} / \mathrm{SiO}_{2}$ (thermal growth $\mathrm{SiO}_{2}$ layer on heavily doped $\mathrm{Si}$ wafer) were sequential rinsed with detergent, DI water, ethanol and acetone. Thin films of $\mathrm{ZnO}$ on different substrates were fabricated by an identical spin coating method at a speed of
$2500 \mathrm{rpm}$ for 50 seconds atroom conditions. The thin films were further annealed at varied temperatures $\left(100,150,200^{\circ} \mathrm{C}\right.$ on a hot plate) for 10 minutes.

\subsubsection{Fabrication of thin film transistors}

Thin film transistors with $\mathrm{ZnO}$ as conducting channel were fabricated by spin coating the $\mathrm{ZnO}$ solution onto $\mathrm{p}^{-\mathrm{Si}^{++}} / \mathrm{SiO}_{2}$ (thickness of the $\mathrm{SiO}_{2}$ was $500 \AA$ ) substrates, which were pre-patterned with $\mathrm{Au}-\mathrm{Cr}$ electrodes allowing channels having a width of $1 \mathrm{~mm}$ and a length of $10 \mu \mathrm{m}$. The coating and annealing procedure was identical to that of $\mathrm{ZnO}$ thin films presented above. For TFT measurements, $\mathrm{ZnO}$ layer on top of metal electrodes were physically crashed out by a sharp tip.

\subsubsection{Fabrication of quantum dot solar cells}

The synthesis of oleic acid capped $\mathrm{PbS}$ quantum dots (QDs) was carried out using a published protocol $[8,9]$. Briefly, a mixture of $\mathrm{PbO}$ (4.2 mmol), 1-octadecene (ODE, $18 \mathrm{ml}$ ), andoleic acid (OA, 8.4-66.5 mmol) wasdegassed at $120{ }^{\circ} \mathrm{C}$ for 2 hours followed sequentially byadjusting to an elevated temperature, from 65 to $130{ }^{\circ} \mathrm{C}$, injection ofbis(trimethylsilyl)sulfide $(2$ mmolin $4 \mathrm{ml}$ ODE), and cooling toroom temperature. The size of the QD was varied by changingtheinjection temperature and/or the amount of added OA. Afterbeing washed once with ethanol andtwice with acetone usingthe typical solvent - non-solvent precipitation procedure, PbSQDswere dispersed in anhydrous n-octane to produce $30 \mathrm{mg} / \mathrm{ml}$ stock solution.

$\mathrm{PbS}$ quantum dot solar cells (QD SCs) were fabricated by developing a $200 \mathrm{~nm}$-thick, 1,2ethenedithiol (EDT) treated PbS QDs layer by a layer-by-layer solid state ligand exchange procedure. Briefly, 3 drops of PbS QDs stock solution was poured onto a spinning FTO/ZnO substrate at $2000 \mathrm{rpm}$ followed by dropping 0.3 $\mathrm{ml}$ solution of $3 \mathrm{vol} \%$ EDT in acetonitrile and then rinsing with acetonitrile to complete one 
coating cycle. Thickness of PbS layer increased by about $25 \mathrm{~nm}$ for each coating cycle [8]. Finally, the films were transfer into a vacuum deposition chamber to deposit Au-Ag electrodes.

\subsection{Characterizations}

The crystalline structure of $\mathrm{ZnO}$ was investigated by $\mathrm{X}$-ray diffraction pattern conducted on a Bruker D5005 diffractometer. I$\mathrm{V}$ characteristics of TFTs were measure on Agilent B2092A. J-V curves of QD SCs were measure by Keithley 2400. The cells were excited with a Xe lamp $450 \mathrm{~W}$ (Newport) calibrated with standard Si cells producing 100 $\mathrm{mW} / \mathrm{cm}^{2}$.

\section{Results and discussion}

$\mathrm{X}$-ray diffraction patterns of $\mathrm{ZnO}$ thin films cured at different annealing temperatures are shown in Figure 1a. All $\mathrm{ZnO}$ films exhibit diffraction peaks at $2 \theta$ of $31.5,34.5,36.2,47.4$, $56.5,62.8$ and 68.2 which, respectively, correspond to the diffractions from (100), (002), (101), (102), 110), (103) and (112) planes of ZnO Wurtzite structure (JCPDS-361451). The XRD peaks were relatively broad because the $\mathrm{ZnO}$ films were thin, about 80-100 $\mathrm{nm}$, and consisted crystalline $\mathrm{ZnO}$ nano-sized domains. Clearly, even at low annealing temperature, e.g. $100{ }^{\circ} \mathrm{C}$, which is boiling point of water, the $\mathrm{ZnO}$ film was crystalline.
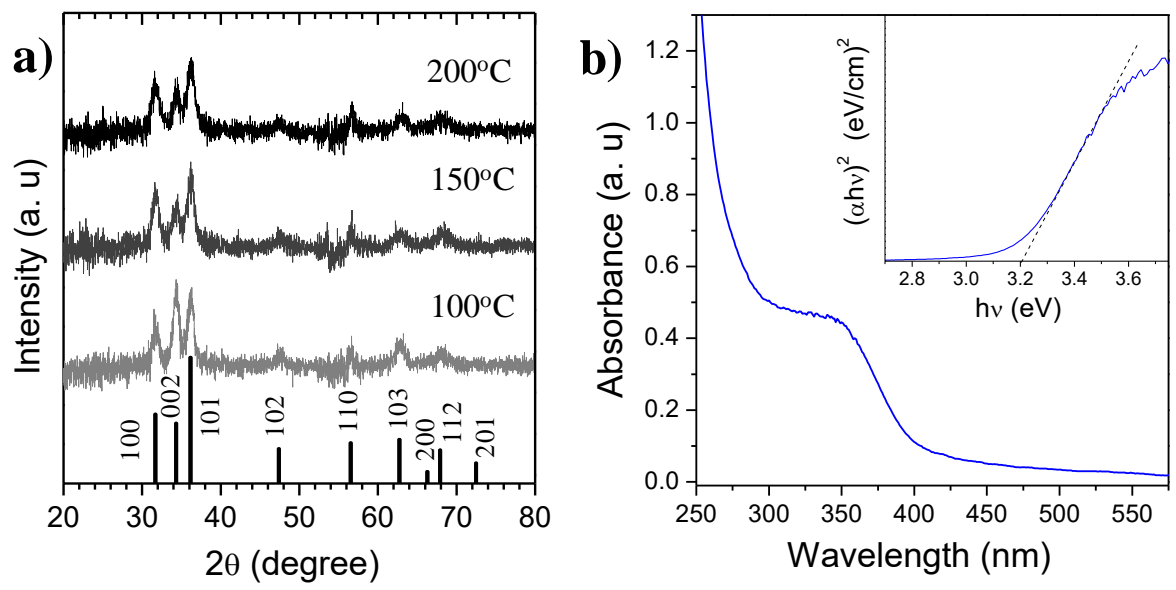

Figure 1.a) X-ray diffraction patterns of $\mathrm{ZnO}$ thin films cured at different temperatures and b) UV-vis absorption spectrum of $\mathrm{ZnO}$ thin film annealed at $100{ }^{\circ} \mathrm{C}$.

It has been well documented the formation of $\mathrm{ZnO}$ from aqueous $\mathrm{ZnCl}_{2}$ solution via $\mathrm{Zinc}$ chloride
$\mathrm{Zn}_{5}(\mathrm{OH})_{8} \mathrm{Cl}_{2} \cdot \mathrm{H}_{2} \mathrm{O} \quad$ (JC-PDF:

01-077-2311) according to the following reactions.

$$
\begin{aligned}
& \mathrm{ZnCl}_{2}+\mathrm{H}_{2} \mathrm{O} \rightarrow\left[\mathrm{ZnOH}{ }_{4-x} \mathrm{Cl}_{x}\right]^{2-} \\
& n\left[\mathrm{ZnOH}{ }_{4-x} \mathrm{Cl}_{x}\right]^{2-} \stackrel{-\mathrm{H}_{2} \mathrm{O}}{\longrightarrow} \mathrm{Zn}_{5} \mathrm{OH}_{8} \mathrm{Cl}_{2} \cdot \mathrm{H}_{2} \mathrm{O} \\
& \mathrm{Zn}_{5} \mathrm{OH}_{8} \mathrm{Cl}_{2} \cdot \mathrm{H}_{2} \mathrm{O} \stackrel{>160^{\circ} \mathrm{C}}{\longrightarrow} \mathrm{ZnO}+\mathrm{ZnO} \cdot \mathrm{ZnCl}_{2} \cdot 2 \mathrm{H}_{2} \mathrm{O}+\mathrm{H}_{2} \mathrm{O} \\
& \left.\mathrm{ZnO} \cdot \mathrm{ZnCl}_{2} \cdot 2 \mathrm{H}_{2} \mathrm{O} \stackrel{>200^{\circ} \mathrm{C}}{\longrightarrow} \mathrm{ZnOH}\right)_{2} \cdot \mathrm{ZnCl}_{2}+\mathrm{H}_{2} \mathrm{O} \\
& \mathrm{ZnOH} \mathrm{OH}_{2} \cdot \mathrm{ZnCl}_{2} \stackrel{>400^{\circ} \mathrm{C}}{\longrightarrow} \mathrm{ZnO}+\mathrm{HCl}
\end{aligned}
$$


The incorporation of $\mathrm{Cl}^{-}$in zinc complexes as well as zinc intermediates requires as high annealing temperature as $400{ }^{\circ} \mathrm{C}$ to fully generate $\mathrm{ZnO}$. In the presence of strong base ligand such as $\mathrm{NH}_{3}$ it replaces $\mathrm{Cl}^{-}$and even $\mathrm{OH}^{-}$ to form complexes such as $\left[\mathrm{Zn}\left(\mathrm{NH}_{3}\right)_{4} \mathrm{OH}{ }_{x}\right]^{(2-x)+}$, which may undergo condensation reaction producing $\mathrm{ZnO}$ cluster stabilized by $\mathrm{NH}_{3}$ ligands like reaction (2). Due to the lack of $\mathrm{Cl}^{-}$in the $\mathrm{ZnO}$ precursor, the removal of $\mathrm{NH}_{3}$ and water solvent during thermal annealing induces further condensation among $\mathrm{ZnO}$ cluster and forming $\mathrm{ZnO}$, thus efficiently reduces the annealing temperature. As shown in Figure 1, an annealing temperature as low as $100{ }^{\circ} \mathrm{C}$ is sufficient to form crystalline $\mathrm{ZnO}$.

The optical properties of low- $\mathrm{T} \mathrm{ZnO}$ films are shown in Figure 1 b. UV-vis absorption spectrum shows characteristic onset at c.a. 400 $\mathrm{nm}$ and a shoulder at about $350 \mathrm{~nm}$. To estimate the bandgap of $\mathrm{ZnO}$, we draw Tauc plot as shown inset in Fig. 1b. The bandgap was calculated to be $3.2 \mathrm{eV}$, which is reasonable for crystalline $\mathrm{ZnO}$.

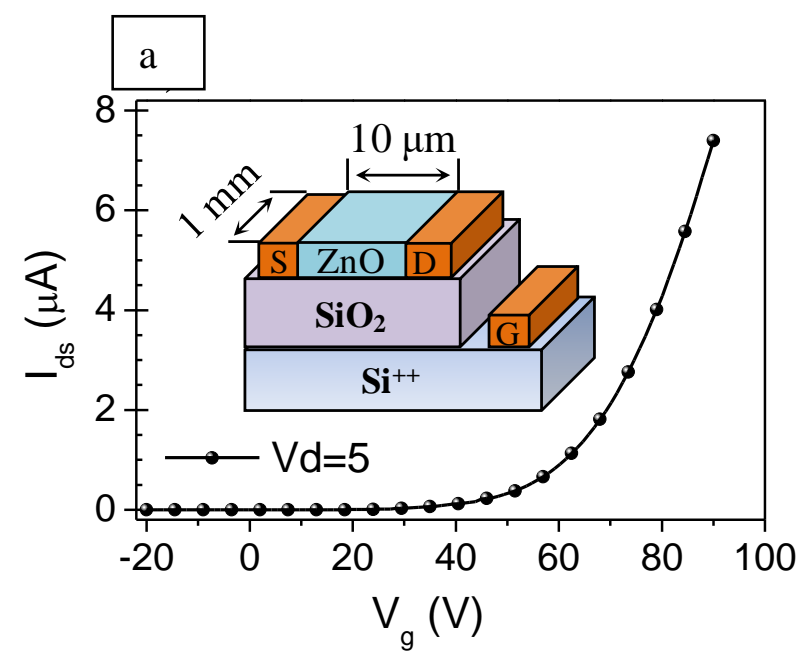

As mentioned previously, although crystalline $\mathrm{ZnO}$ films could be formed at temperature as low as $100^{\circ} \mathrm{C}$ for electrical applications water has to be eliminated. Therefore, we used annealing temperature of $150^{\circ} \mathrm{C}$ for TFT and solar cells fabrications.

Electrical properties of low-temperature $\mathrm{ZnO}\left(150{ }^{\circ} \mathrm{C}\right)$ thin films was studied by TFT and the results are shown in figure 2. Figure 2 shows that the drain current $\left(I_{\mathrm{ds}}\right)$ increase when the gate voltage $\left(\mathrm{V}_{\mathrm{g}}\right)$ increase positively, indicating that the low-temperature $\mathrm{ZnO}$ is an n-type semiconductor. Linear electron mobility $\mu_{\text {lin }}$ of $\mathrm{ZnO}$ was estimated by using equation: $\mu_{l i n}=\frac{\delta I_{d s}}{\delta V_{g}} \frac{L}{W C V_{d s}}$ where $\frac{\delta I_{d s}}{\delta V_{g}}$ is the slope of transfer cuver; $L$ and $W$ are the length $(10 \mu \mathrm{m})$ and the width $(1 \mathrm{~mm})$ of the channel; $V_{d s}=5 \mathrm{~V}$ is the drain voltage; and $C$ is capacitance $C=\frac{k}{\varepsilon_{o} d}$ with $k, \varepsilon_{o}, d$ are the dielectric constant of $\mathrm{SiO}_{2}$ (3.8), vacuum permittivity, and thickness of the $\mathrm{SiO}_{2}$ dielectric layer ( $500 \AA)[10]$. The calculated electron mobility was $0.09 \mathrm{~cm}^{2} \mathrm{~V}^{-1} \mathrm{~s}^{-1}$.

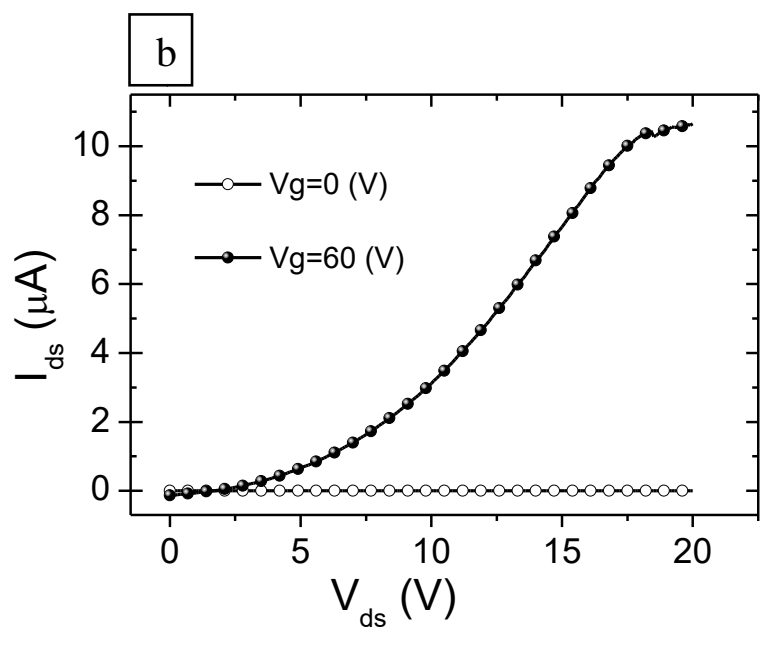

Figure 2. Properties of TFT with $\mathrm{ZnO}$ as conducting channel.

a) Transfercurve and b) output curves of $\mathrm{ZnO}$ TFT device. Inset in a) is TFT structure. 
a)

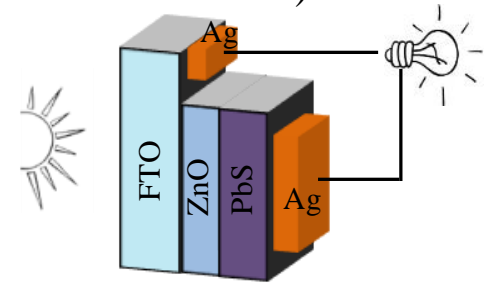

b)

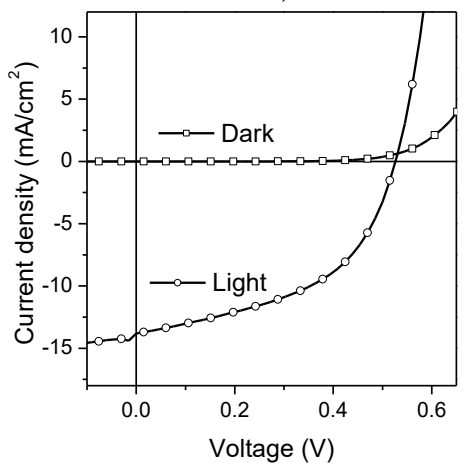

Figure 3. a) Structure and b) J-V characteristics of quantum dot solar cells with $\mathrm{ZnO}$ as $n$-type layer.

For comparison, the conventional sol-gel $\mathrm{ZnO}$ typically require an annealing temperature above $250{ }^{\circ} \mathrm{C}$, depending on $\mathrm{Zn}$ precursor and stabilizing additives [11]. For example, synthesis of $\mathrm{ZnO}$ thin film from mixture of Zinc acetate and monoethanolamine requires annealing temperatures greater than $250^{\circ} \mathrm{C}$ [12]. These high temperatures are not only to conduct condensation reaction among $\mathrm{Zn}-\mathrm{OH}$ groups but also to eliminate residual amine additives as well as solvents. In our reaction scheme, labile $\mathrm{NH}_{3}$ was used to stabilize $\mathrm{ZnO}$ cluster in solution state. The easy removal of $\mathrm{NH}_{3}$ and, probable decomposition of $\mathrm{NH}_{4} \mathrm{Cl}$ only need low temperatures, e. g $100{ }^{\circ} \mathrm{C}$ to perform crystalline $\mathrm{ZnO}$ films. $\mathrm{NH}_{3}$ solution has been used previously to dissolve $\mathrm{ZnO}$ performing $\mathrm{ZnO}$ ink for low-temperature TFTs [13]. Easy volatile $\mathrm{NH}_{3}$ ligand was discussed to be the key factor to reduce annealing temperature to about $150{ }^{\circ} \mathrm{C}$. This annealing temperature is still higher than the annealing temperature demonstrated in this study. However, the TFT electron mobility of our low- $\mathrm{T} \mathrm{ZnO}$ is 0.09 $\mathrm{cm}^{2} \mathrm{~V}^{-1} \mathrm{~s}^{-1}$, which is lower than the value reported in reference 13 , of about $0.4 \mathrm{~cm}^{2} \mathrm{~V}^{-1} \mathrm{~s}^{-1}$ on $\mathrm{ZnO}$ annealed at $150{ }^{\circ} \mathrm{C}$ in $\mathrm{N}_{2}$ atmosphere. It is worthy to note that electron mobility is only one of many physical properties that determine the performance of photoelectronic devices such as solar cells. The other importance factors include trapping density aligning below the conduction band level, energy level of conduction band, carrier concentration, transparency, and carrier diffusion length.

To realize the application potential of lowtemperature $\mathrm{ZnO}$ in emerging solar cells, we fabricated quantum dot solar cells having structure of $\mathrm{FTO} / \mathrm{ZnO} / \mathrm{PbS} / \mathrm{Au}-\mathrm{Ag}$. The structure and $\mathrm{J}-\mathrm{V}$ characteristics of cell are summarized in Figure 3. For further detail information related to the synthesis of $\mathrm{PbS}$ quantum dots, quantum dot thin film fabrications, and electrode deposition, the readers may look at our previous publication [8]. Dark curve of the cell shows negligible current when applied voltage below $0.4 \mathrm{~V}$. This is rectifying property of $\mathrm{PbS}-\mathrm{ZnO} p-n$ junction. Under AM1.5 illumination, the J-V curve shifted down giving rise an open circuit voltage of $0.5 \mathrm{~V}$, a short-circuit current density of 14 $\mathrm{mAcm}^{-2}$ and a fill factor of $48 \%$. The corresponding power conversion efficiency was $3.1 \%$.

\section{Conclusions}

The present study demonstrates the use of $\mathrm{NH}_{3}$ stabilized $\mathrm{ZnO}$ precursor to fabricate $\mathrm{ZnO}$ thin films at temperatures below $200{ }^{\circ} \mathrm{C}$. $\mathrm{ZnO}$ films annealed at $150^{\circ} \mathrm{C}$ exhibits good electron conductivity with a linear mobility of 0.09 $\mathrm{cm}^{2} \mathrm{~V}^{-1} \mathrm{~s}^{-1}$ and it is fully compatible with emerging quantum dot solar cells. The possibility of fabrication of $\mathrm{ZnO}$ based on 
solution process under temperatures below $200^{\circ} \mathrm{C}$ promise future developments of flexible electronics and optoelectronics.

\section{Acknowledgements}

This research was fundedby National Research Foundation for Science \& Technology Development under grant number: 103.992016.32.

\section{References}

[1] A. Janotti, A. Janotti, C.G. Van De Wallefundamental of $\mathrm{ZnO}$ as a semiconductor, Reports on Progress in Physics, 72 (2009) 126501.

[2] H. You, Y. Lin-investigation of the sol-gel method on the flexible $\mathrm{ZnO}$ device, International Journal of Electrochemical Science, 7 (2012) 9085-9094.

[3] Y. Lin, C. Hsu, M. Tseng, J. Shyue, F. Tsai-stable and high-performance flexible $\mathrm{ZnO}$ thin-film transistors by atomic layer deposition, Applied Materials \&Interfaces, 7(40) (2015) 22610 22617.

[4] C. Lin, S. Tsai, M. Chang-Spontaneous growth by sol-gel process of low temperature $\mathrm{ZnO}$ as cathode buffer layer in flexible inverted organic solar cells, Organic Electronics, 46 (2017) 218 255.

[5] H. Park, I. Ryu, J. Kim, S. Jeong, S. Yim, S. Jang$\mathrm{PbS}$ quantum dot solar cells integrated with sol-gel-derived $\mathrm{ZnO}$ as an n-type charge-selective layer, Journal of Physical Chemistry C, 118(2014) 17374-17382.
[6] Y. Sun, J.H. Seo, C.J. Takacs, J. Seifter, A.J. Heeger-inverted polymer solar cells integrated with a low- temperature-annealed sol-gel-derived $\mathrm{ZnO}$ film as an electron transport layer Advanced Materials, 23(2011) 1679-1683.

[7] V.A. Online, R. Suriano, C. Bianchi, M. Levi, S. Turri, G. Griffini-the role of sol-gel chemistry in low-temperature formation of $\mathrm{ZnO}$ buffer layers for polymer solar cells with improved performance, RSC Advances, 6(2016) 4691546924.

[8] X. D. Mai, J. An, H. Song, J. Jang-inverted Schottky quantum dot solar cells with enhanced carrier extraction and air-stability, Journal of Materials Chemistry A, 2 (2014) 20799-20805.

[9] H. Choi, J. Lee, X.D. Mai, M.C. Beard, S.S. Yoon, S. Jeong - supersonically spray-coated colloidal quantum dot ink solar cells, Scientific Report, 7(2017) 622.

[10] C.R. Newman, C.D. Frisbie, A. Demetrio, S. Filho, J. Bre- introduction to organic thin film transistors and design of n-channel organic semiconductors, Chemistry Materials, 16(2004) 4436-4451.

[11] M. Asad, N. Abdul, Chapter 9: Sol-Gel-Derived Doped ZnO Thin Films: Processing, Properties, and Applications, in Recent Applications in SolGel Synthesis, Edt:C. Usha. InTech, Rijeka, Croatia, 2017.

[12] D. Guo, K. Sato, S. Hibino, T. Takeuchi, H. Bessho, K. Kato, Low-temperature preparation of (002)-oriented $\mathrm{ZnO}$ thin films by sol-gel method, Thin Solid Films, 550 (2014), 250-258.

[13] S. T. Meyers, J. T. Anderson, C. M. Hung, J. Thompson, J. F. Wager, D. A. Keszler, Aqueous Inorganic Inks for Low-Temperature Fabrication of ZnO TFTs, J. Am. Chem. Soc, 130 (2008), 17603-17609. 


\title{
Màng Mỏng ZnO Nhiệt Độ Thấp và Ứng Dụng Của Nó Trong Pin Mặt Trời Sử Dụng Chấm Lượng Tử PbS
}

\author{
Mai Xuân Dũng ${ }^{1}$, Hoàng Quang Bắc ${ }^{1}$, \\ Đinh Thị Châm ${ }^{1}$, Lê Quang Trung ${ }^{1}$, Nguyễn Trọng Tùng ${ }^{2}$ \\ Dương Ngọc Huyền ${ }^{2}$, Mai Văn Tuấn ${ }^{2,3}$, Lê Đình Trọng ${ }^{4}$ \\ ${ }^{1}$ Khoa Hóa học, Truờng Đại học Su phạm Hà Nội 2, số 32 Nguyễn Văn Linh, Phúc Yên, Vĩnh Phúc \\ ${ }^{2}$ Viện Vật lý Kỹ thuật, Đại học Bách khoa Hà Nội, 1 Đại Cổ Việt, Hà Nội, Việt Nam \\ ${ }^{3}$ Khoa Khoa học Tự nhiên, Trường Đại học Điện lực, 235 Hoàng Quốc Việt, Hà Nội, Việt Nam \\ ${ }^{4}$ Khoa Vật lý, Truoòng Đại học Su phạm Hà Nội 2, 32 Nguyễn Văn Linh, Phúc Yên, Vĩnh Phúc, Việt Nam
}

Tóm tắt: Pin mặt trời sử dụng các chất bán dẫn tiềm năng như chấm lượng tử, perovskite và bán dẫn hữu cơ đang ngày được nghiên cứu nhiều hơn với kỳ vọng giảm giá thành và tăng hiệu suất chuyển hóa năng lượng (PCE). ZnO là một trong các oxit kim loại trong suốt được tích hợp rộng rãi trong các loại pin mặt trời trên để làm vật liệu truyền dẫn electron. Do đó, giảm nhiệt độ thiêu kết $\mathrm{ZnO}$ là đòi hỏi cốt lõi để có thể chế tạo pin mặt trời giá rẻ bằng cách sử dụng các kỹ thuật chế tạo sử dụng dung dịch như in, phủ quay. Trong bài báo này chúng tôi trình bày một dung dịch tiền chất $\mathrm{ZnO}$ mới lạ, bền hóa bởi phối tử dễ bay hơi $\mathrm{NH}_{3}$ cho phép chế tạo màng $\mathrm{ZnO}$ tinh thể ở nhiệt độ dưới $200^{\circ} \mathrm{C}$. Transistor và pin mặt trời đã được chế tạo sử dụng $\mathrm{ZnO}$ làm lớp dẫn điện tử. Trong pin mặt trời chấm lượng tử, lớp chấp lượng tử $\mathrm{PbS}$ với độ rộng vùng cấm là $1,4 \mathrm{eV}$ được phủ quay bên trên lớp $\mathrm{ZnO}$ bằng phương pháp trao đồi phối tử pha rắn với 1,2-ethylenedithiol. Nghiên cứu trên transistor cho thấy $\mathrm{ZnO}$ có linh độ electron là $0.09 \mathrm{~cm}^{2} \mathrm{~V}^{-1} \mathrm{~s}^{-1}$. Hiệu suất làm việc của pin mặt trời chấm lượng tử là $3.0 \%$ ở điều kiện chiếu sáng tiêu chuẩn $\mathrm{AM} 1.5$. Các kết quả này cho thấy việc chế tạo $\mathrm{ZnO}$ ở nhiệt độ thấp cóvai trò quan trọng trong việc chế tạo các thiết bị điện tử và quang điện tử với giá thành thấp.

Tù khóa: $\mathrm{ZnO}$, màng mỏng, pin mặt trời, transitors. 